University of Wollongong

Research Online

Sydney Business School - Papers

Faculty of Business and Law

$1-1-2019$

\title{
Patterns of recruitment of academic leaders to Australian universities and implications for the future of higher education
}

\section{Susan Loomes}

University of Notre Dame, sll424@uowmail.edu.au

Alison Owens

Central Queensland University, a.owens@cqu.edu.au

Grace McCarthy

University of Wollongong, gracemc@uow.edu.au

Follow this and additional works at: https://ro.uow.edu.au/gsbpapers

Part of the Business Commons

\section{Recommended Citation}

Loomes, Susan; Owens, Alison; and McCarthy, Grace: Patterns of recruitment of academic leaders to Australian universities and implications for the future of higher education 2019, 137-152.

https://ro.uow.edu.au/gsbpapers/560

Research Online is the open access institutional repository for the University of Wollongong. For further information contact the UOW Library: research-pubs@uow.edu.au 


\title{
Patterns of recruitment of academic leaders to Australian universities and implications for the future of higher education
}

\author{
Abstract \\ This paper reports on research conducted to understand key factors impacting the recruitment and \\ selection of senior academic leaders in Australian universities. A key finding emerging from this research \\ was an increasing reliance on executive search firms when recruiting senior academic leaders. This \\ reliance is driven by a range of factors including an ageing and contracting pool of potential academic \\ leaders, growing competition domestically and internationally and the declining attractiveness of \\ academia as a sustainable career in the context of increased casualisation of the academic workforce. \\ Concurrently, workforce planning and succession planning have not been a high priority for many \\ universities. As a result, Australian universities are finding it increasingly difficult to recruit senior \\ academic leaders without the use of executive search firms. These findings have significant implications \\ for the higher education sector in Australia and warrant further research.

\section{Disciplines \\ Business}

\section{Publication Details} \\ Loomes, S., Owens, A. \& McCarthy, G. (2019). Patterns of recruitment of academic leaders to Australian \\ universities and implications for the future of higher education. Journal of Higher Education Policy and \\ Management, 41 (2), 137-152.
}




\title{
PATTERNS OF RECRUITMENT OF ACADEMIC LEADERS TO AUSTRALIAN UNIVERSITIES AND IMPLICATIONS FOR THE FUTURE OF HIGHER EDUCATION
}

\author{
Dr Susan Loomes \\ Executive Director, Business Operations \\ Notre Dame University, Sydney Campus \\ Associate Professor Alison Owens \\ Central Queensland University \\ Associate Professor Grace McCarthy \\ Dean Sydney Business School \\ University of Wollongong
}

\begin{abstract}
This paper reports on research conducted to understand key factors impacting the recruitment and selection of senior academic leaders in Australian universities. A key finding emerging from this research was an increasing reliance on executive search firms when recruiting senior academic leaders. This reliance is driven by a range of factors including an aging and contracting pool of potential academic leaders, growing competition domestically and internationally and the declining attractiveness of academia as a sustainable career in the context of increased casualisation of the academic workforce. Concurrently, workforce planning and succession planning have not been a high priority for many universities. As a result, Australian universities are finding it increasingly difficult to recruit senior academic leaders without the use of executive search firms. These findings have significant implications for the higher education sector in Australia and warrant further research.
\end{abstract}

KEYWORDS: Recruitment, Selection, Universities, Executive Search, Workforce Planning

\section{INTRODUCTION}

This paper provides insights drawn from research conducted into the changing nature of recruitment and selection of senior academic leaders in Australian universities focusing on the growing dependence and influence of executive search firms in tertiary education. It firstly provides a summary of the factors impacting the university recruitment and selection process, such as growing competition for academic staff, an aging academic workforce, the declining attractiveness of academia, and the lack of succession planning by Australian universities. Secondly, and in this context, this paper reports in some detail, research findings related to the growing reliance on executive search firms in the recruitment and selection of senior academic leaders in Australian universities and discusses the possible implications.

\section{BACKGROUND}

\section{The Changing Landscape of Australian Universities}

Australian universities are working in a dynamic and ever-changing environment. They face an array of challenges from both a macro-environmental and an internal perspective (Kent, 2006; Middlehurst, Goreman, \& Woodfield, 2009). These challenges place them in a high-risk position not traditionally associated with universities (Fullan \& Scott, 2009). Universities have been placed under significant pressure with declining government funding as a proportion of 
income and have been forced to become more corporate or business-like (Brown \& Moshavi, 2002; Harman, 2003; Kent, 2006; Middlehurst et al., 2009; Wolverton \& Poch, 2000; Yielder \& Codling, 2004). As a result, universities need to attract additional revenue, control costs and address growing competition for students. To address this revenue shortfall, many universities have recruited large numbers of international students. Short-term this is not a concern, however, the international student market can be volatile and may not be sustainable long term.

From a macro-environmental perspective, one of the main challenges for higher education in Australia has been the constant change of policy by the Australian Government. The following chart provides a summary of some of the key policies that have impacted universities over the last 30 years. The constant changes in government policy as outlined in Table 1 have made managing universities more complex and challenging. The ability to recruit high quality senior academic leaders to manage this ever changing environment is crucial to the success and sustainability of the sector.

\begin{tabular}{|c|c|c|}
\hline Year & Policy & $\begin{array}{c}\text { Reviews/Changes } \\
\end{array}$ \\
\hline 1989 & $\begin{array}{l}\text { Higher } \\
\text { Contribution } \\
\text { introduced }\end{array}$ & $\begin{array}{l}\text { Shifted a significant proportion of the cost of } \\
\text { higher education from the Commonwealth to } \\
\text { students. Under the original HECS, a } \$ 1,800 \text { fee } \\
\text { was charged to all university students, and the } \\
\text { Commonwealth paid the balance. A student could } \\
\text { defer payment of this HECS amount (in which } \\
\text { case it was called a HECS debt) and repay the } \\
\text { debt through the tax system, when the student's } \\
\text { income exceeds a threshold level. }\end{array}$ \\
\hline 1997 & $\begin{array}{l}\text { West Committee Review of } \\
\text { Higher Education Financing } \\
\text { and Policy }\end{array}$ & $\begin{array}{l}\text { West Review, Chaired by Roderick West } \\
\text { recommended three main changes. Funding to be } \\
\text { student centred, research to be a priority and to } \\
\text { invest in IT and the infrastructure required to } \\
\text { support it (West, 1998). }\end{array}$ \\
\hline 2008 & Bradley Review & $\begin{array}{l}\text { Reported on the future direction of the higher } \\
\text { education sector making recommendations for } \\
\text { reform and continuous improvement such as the } \\
\text { demand-driven funding model. The review found } \\
\text { Australia was falling behind other countries in } \\
\text { performance and investment in higher education } \\
\text { (Bradley, Noonan, Nugent, \& Scales, 2008). }\end{array}$ \\
\hline 2010 & $\begin{array}{l}\text { The Knight Review was } \\
\text { commissioned by } \\
\text { Department of Immigration } \\
\text { and Department of Education } \\
\text { (DEEWR) }\end{array}$ & $\begin{array}{l}\text { Knight Report recommends a number of } \\
\text { incremental changes to improve the performance } \\
\text { of the student visa system (Creagh, 2011; } \\
\text { Department of Education and Training, 2011). }\end{array}$ \\
\hline 2011 & $\begin{array}{l}\text { Tertiary Education Quality } \\
\text { and Standards Agency } \\
\text { (TEQSA) was formed. }\end{array}$ & $\begin{array}{l}\text { Established as a result of the Bradley Review. } \\
\text { Regulates and assures the quality of higher } \\
\text { education in Australia (Mazzolini, 2012). }\end{array}$ \\
\hline 2011 & $\begin{array}{l}\text { TEQSA introduced the } \\
\text { Higher Education Standards } \\
\text { Framework } \quad \text { (Threshold } \\
\text { Standards) } 2011\end{array}$ & $\begin{array}{l}\text { Higher education providers in Australia are to } \\
\text { comply with the Commonwealth Government's } \\
\text { Threshold Standards, which form part of the } \\
\text { Higher Education Standards Framework } \\
\text { (Department of Education and Training, 2011). }\end{array}$ \\
\hline
\end{tabular}




\begin{tabular}{|c|l|l|}
\hline 2012 & Student Visa Program & $\begin{array}{l}\text { Aimed to simplify the visa application process for } \\
\text { international students requiring reduced } \\
\text { evidential requirements when applying for a } \\
\text { student visa (Department of Immigration and } \\
\text { Citizenship, 2012). }\end{array}$ \\
\hline 2016 & $\begin{array}{l}\text { Simplified Student Visa } \\
\text { Framework }\end{array}$ & $\begin{array}{l}\text { Aimed to reduce red-tape and create a level } \\
\text { playing field for all education providers } \\
\text { (Australian Government, 2015a, 2016c). }\end{array}$ \\
\hline 2016 & $\begin{array}{l}\text { Excellence in Research for } \\
\text { Australia (ERA) }\end{array}$ & $\begin{array}{l}\text { Australian Government declared a shift in the } \\
\text { focus of ERA from general scholarly activity } \\
\text { (measured by publications) to research that drives } \\
\text { innovation and foster collaboration between } \\
\text { universities and businesses (Australian } \\
\text { Government, 2016b). }\end{array}$ \\
\hline 2017 & $\begin{array}{l}\text { Revised Higher Education } \\
\text { Standards } \\
\text { (Threshold Standards) 2015 }\end{array}$ & $\begin{array}{l}\text { Standards were re-structured to align with the } \\
\text { student experience or 'student life cycle' } \\
\text { (Australian Government, 2017d). New Standards } \\
\text { were introduced. }\end{array}$ \\
\hline End of the demand driven & $\begin{array}{l}\text { Australian Government put a two year freeze on } \\
\text { universities funding for, 2018 and 2019 affecting } \\
\text { Commonwealth Supported Places funding } \\
\text { (Norton, 2017). }\end{array}$ \\
\hline
\end{tabular}

Table 1: Some of the policy changes that have impacted higher education providers in Australia

In a recent report by Ernst \& Young, they state:

'The university leaders we interviewed know they need to act with urgency to prepare their institutions to compete in a very different world to today. They are also operating within a funding and policy context that makes such changes difficult, meaning that any solutions will require government and university collaboration to address (2018 p.4)'

In 2017, Universities Australia observed that a more stable policy and funding environment was vital in securing Australia’s future (Knott, 2017).

\section{Research Question}

This paper reports from broader research conducted to better understand the recruitment and selection of senior academic leaders in Australian universities, generally, with the following research questions:

1. What factors affect the recruitment and selection of senior academic leaders?

2. How are Australian universities recruiting and selecting their senior academic leaders?

3. What role do executive search companies play in the recruitment and selection of senior academic leaders?

4. What are Australian universities looking for when recruiting senior academic leaders?

This paper reports and discusses the findings most directly related to question number three which focuses on the role of executive search companies in the recruitment and selection of 
senior academic leaders in Australian Universities. However information relevant to this topic was also drawn from questions one and two. This is because the influence of executive search firms in the recruitment of senior academic leaders was an unexpected and significant finding.

\section{RESEARCH PARAMETERS}

Research participants were drawn from the 39 (there are now 41) Australian universities and three executive search organisations. To obtain a better understanding of who are the senior academic leaders in Australian universities, the researcher conducted an analysis of their senior-leadership structures via university websites. This entailed reviewing organisational charts and university executive structures, and digging deep into faculty pages. The results revealed that the role of Vice Chancellor was consistent across all universities, whereas four universities did not have the role of Deputy Vice Chancellor (sometimes referred to as Provost). Approximately 30 per cent of universities did not have the position of Pro-Vice Chancellor. The role of Executive Dean is an emerging trend evident in one-third of the universities and is supported by a Dean, Associate Dean or Deputy Dean. All universities have the faculty Dean role or equivalent and there is wide recognition of the importance of this role: "the fault line between managers and academic staff falls somewhere between the faculty dean and individual staff,” (Marginson \& Considine, 2000 p.4).

After reviewing the university structures, a decision was made to focus on the recruitment and selection of Pro-Vice Chancellors, Deputy Vice Chancellors, Executive Deans and Deans (or equivalent) because of the significant role they play within the university senior academic leadership structure. In addition, the role of Head of School was included in the research, as their role is pivotal in the implementation of the university's strategy. Whilst Vice Chancellors clearly play a significant role within the university, the researcher did not include them in this research because the method by which they are recruited and selected is different from other senior leaders.

Senior staff holding leadership roles in the universities' human resource departments were chosen to be interviewed, as they are heavily involved in, and responsible for, the recruitment and selection of senior academic leaders, whether conducted in-house or through executive search companies. In their role they see recruitment and selection from a university-wide perspective as well as a case-by-case basis. Further, it was assumed that as they have experience in a senior human resource role, they would have extensive knowledge of and familiarity with recruitment and selection.

As the pivotal role of executive search firms in the selection and recruitment process emerged in these interviews, further interviews were conducted with three executive search companies specialising in higher education leadership recruitment and a comprehensive literature review was undertaken.

\section{METHOD}

A qualitative approach was adopted for this research as the researcher sought to gain an indepth and rich account of the processes of recruitment and selection of senior academic staff at Australian universites. Interpretive methods of data collection and analysis were deployed on the assumption that truth can be established through communication with individuals and the sharing of experiences within our lived world, which are negotiated through ongoing discussion and dialogue (Angen, 2000). A multiple case study approach was adopted, enabling an in-depth exploration of the recruitment and selection process of senior academic leaders in ten Australian universities. Through a process of purposive sampling, research participants 
with responsibility for provision and management of human resources at each of the 39 Australian universities were invited to participate in the research. As a result, ten university human resource managers attended individual face to face interviews with the researcher. These participants were drawn from the five categories of Australian Universities: Group of Eight, Regional Universities Network, Australian Technology Network of Universities, Innovative Research Universities and 'non aligned' universities that did not fall into the more formal groupings. This spread of participants across University categories allowed an inclusive and wide-ranging perspective on the Australian university sector. Interview questions sought to elicit the views and experiences of these university staff in their efforts to recruit senior academic staff to leadership positions.

As previously mentioned, a strong finding emerging early in the interview process was the degree on dependence of universities on executive search firms for recrutiment of senior staff. Consequently, managers of three executive search organisations were also interviewed to elicit their insights into their role in the recruitment and selection of senior academic leaders. All interviews with university staff and executive search firms were recorded and transcribed for analysis using NViVO software. This paper presents and analyses data relating to the role of executive search firms in the recruitment and selection of senior academic leaders in Australian universities.

An opportunity to gather additional data emerged at the Higher Education Workforce Planning and Policy Conference 2012 attended by senior university human resource managers. As a presenter at the conference, the author asked conference attendeees to provide written responses to emerging findings from interview research. These responses were taken into account in interpreting the interview findings.

\section{DISCUSSION}

\section{Factors Impacting the Recruitment of Senior Academic Leaders in Australian Universities}

The research identified four key factors impacting the recruitment and selection of senior academic leaders in Australian universities: 1) growing competition, 2) an aging academic workforce, 3) the declining attractiveness of academia as a profession and 4) a lack of succession planning. The following section discusses these factors and how they are impacting the recruitment and selection of senior academic leaders.

\section{Growing Competition}

Because of the way universities are now funded and the impact of globalisation, universities are now in direct competition for rankings, students and academic staff (Ernst \& Young, 2018; Fullan \& Scott, 2009; Scott, Coates, \& Anderson, 2008). Competitors include other universities from within Australia, from overseas as well as private companies such as Navitas and Laureate International Universities, vocational education institutions such as Technical and Further Education (TAFE), and also professional associations such as Chartered Professional Accountants (CPA) and Australian Computer Society (ACS).

Scott, Coates and Anderson, in their Australian Learning and Teaching Council report (2008) Learning Leaders in Times of Change Academic Leadership Capabilities for Australian Higher Education highlighted the increasing pressures on universities and in particular, growing competition for staff and students from within Australia and from overseas (Scott et al., 2008). 
Australian universities will continue to face unrelenting competition for international students from traditional competitor countries. Universities Australia states:

\begin{abstract}
'international education is under increasing pressure from traditional competitors such as the UK and the US but more importantly from emerging nations such as China, Singapore and Malaysia, who seek to replicate the outstanding success Australia has experienced in international education (Universities Australia, 2012 p16).'
\end{abstract}

Further a report prepared for Austrade by Deloittes suggest that Australia will face stronger competition for international students as the domestic education systems in markets such as China improve in quality and capacity (Deloittes Access Economics, 2015).

Ernst \& Young reported that along with the traditional competitors there is also the threat of technological disruption to traditional university models. The report states:

'In the US, shopping malls and department stores are failing at a rate of 1 in 5 as consumers shift to online retailing - and the trend is starting to be felt in Australia too. Technology is impacting education in a similar way, as learning moves online. Universities need to reconsider the role of the campus in a future where digital learning models dominate and space, place and time are less important (Ernst \& Young, 2018 p.p21)'.

Further, competition is increasing from rising Asian universities along with well know branded international universities enticing domestic students with digital course offerings (Ernst \& Young, 2018).

Participants in this study reinforced the view of $\mathrm{Ng}$ (2013) who reports an emerging global talent war between many economies as the pool of academic talent shrinks and becomes more globally mobile. Countries such as those in Asia and the Middle East are gaining traction in this space and becoming fierce competitors for talent. Whilst Ng's research emanates out of Singapore, it is interesting to note that the findings from his study are consistent with those reported in an Australian context. Consistent with Stone (2011) participants stated that as the academic talent pool gets smaller, there is a growing need to go international for quality talent, and confirmed a shift to global appointments using international attraction strategies. One university participant stated 'it used to be somewhat 'exotic' to attract a candidate from overseas; however, this is normal practice these days'. Another said:

'If the Australian dollar drops down too, we will lose our ability to compete on a salary level. You know, they are the sorts of risks that we potentially run into down the track. Right now it's all a perfect storm a little bit for us, because things aren't that rosy there at the moment, so Australia looks very attractive, but that can change just as quickly'.

As the sector faces growing competition from global competitors and digital disruptions it will need to be prepared for this unprecedented pace of change (Deloittes Access Economics, 2015).

\title{
Aging Academic Workforce
}

Australian universities need to contend with an aging population and subsequent aging academic workforce (Bexley, Arkoudis, \& James, 2012; Group of Eight, 2012; Hugo \& 
Morriss, 2010; Larkin \& Neumann, 2012; Noonan \& Pilcher, 2018). Graeme Hugo, of the National Centre for Social Application of Geographic Information Systems, has been reporting on the significant implications of the aging academic workforce since 2004. He has alarmingly reported that universities would be drastically affected by the declining academic workforce, noting that 'between a fifth and a third of their staff will retire in the next decade' (Hugo, 2005 p20) and that some universities may lose half of their leadership in the next five years (Hugo \& Morriss, 2010).

Since that time a report by Ernst \& Young in 2012 suggested that the academic workforce is aging more than the rest of the workforce stating that 'a quarter of Australia's academic workforce is aged 55 and over, compared to 15 per cent for the rest of the workforce in Australia' (Ernst \& Young, 2012 p.24). In 2017, there has been little change, with around 23 per cent of the academic workforce being over 55. Drilling down into the data further it shows that 42 per cent of academic staff, at senior lecturer and above (full-time and fractional), are over the age of 55 (Australian Government, 2017). Whilst this data raises concerns, the LH Martin Institute suggests that this impact may be more gradual than first anticipated due to people phasing into retirement (Group of Eight, 2014).

As the baby boomers withdraw from the academic workforce, Australian universities may be faced with an increasing need to recruit from overseas (Archer, 2005; Bexley et al., 2012; Fullan \& Scott, 2009; Kent, 2006; McCarthy \& Loomes, 2011). In the context of the escalating global war for talent, Fullan and Scott (2009) warn that, 'The 1970s strategy of filling the gap through recruitment of academics from overseas will not work'. Already 40 per cent of our academic workforce are born overseas compared to 25.7 per cent of the Australian workforce (Universities Australia, 2016).

Whilst the literature suggests that the aging academic workforce has the potential to affect the university academic workforce significantly, surprisingly it appears that universities are not arming themselves with strategies to address the looming under-supply. Two university research participants did identify the aging workforce as a major concern with comments such as, 'I think the aging workforce means the pool is becoming more challenging for everyone'. However, the majority of university and executive search participants thought that the aging academic workforce was an issue, not so much now, but in the future.

One reason it does not appear to be an issue now is because high-quality academics can still be sourced from overseas. This is due in part to Australia being an attractive destination for senior academic leaders, particularly from countries that have been faced with poor economic conditions since the global financial crisis (Cox, 2010). Participants acknowledged that these conditions can change rapidly: a change in the Australian dollar or improved economic conditions in other countries could abruptly leave Australian universities in a vulnerable position in vying for high-quality talent. On the other hand, Britain's decision to leave the European Union and the current political landscape in the US may lead to an influx of academics from these countries to Australia.

On a positive note, universities in this study do not seem to have any prejudices around hiring older academics. One of the executive search participants said that convincing a panel to consider a younger candidate for senior roles could sometimes be more challenging. What all participants raised as being important, however, was the candidate's 'fitness for the job' in other words, whether they had maintained their youth, vitality and energy levels and remained intellectually nimble. 


\section{Declining Attractiveness of Academia}

While historically a job in a university was a job for life, all participants in this study observed the diminishing attractiveness of academia due to decreased tenured positions. This is consistent with Coates and fellow researchers (Coates et al., 2009; Coates \& Goedegebuure, 2012; Coates, Goedegebuure, Van Der Lee, \& Meek, 2008), who have warned that universities need to ensure the academic profession remains attractive. Participants made comments such as:

'So I think the profession of academia has got a lot to worry about and many are not being put into tenured positions' (University).

'Generally speaking...one of the current major challenges is, most universities in Australia are looking to do away with the notion of tenure' (Executive Search).

Whilst the Grattan Report (Norton, 2013) stated that most academic staff do not have ongoing employment, it did not specifically report on the length of contract for senior academic leader appointments. Participants in this study stated that in most cases, senior academic appointments were typically short-term contracts (three to five years) providing limited job security.

Participants in this research reported their university was already having an increasing problem recruiting senior academics to specific disciplines such as accounting, law, engineering, marketing and medical-related areas, i.e. disciplines related to professional occupations with higher remuneration and job security than available at universities. Similar findings were reported in a paper released a decade ago by Universities UK (2007).

\section{Lack of Succession Planning}

One of most significant issues raised by all participants was the lack of succession planning and the lack of established 'pipelines' in Australian universities consistent with research by Larkin and Neumann (2012). Although universities are investing a significant amount of money into recruitment, they are not all investing in developing their own leaders from within.

One university participant said 'universities talk about workforce planning and succession planning, I've not yet seen a university that has a handle on it'.

Other participants stated:

'I think that universities are too afraid to talk succession planning because of the worries about merit. It is a major missed opportunity and risk area' (Executive Search).

'I say that succession planning is important, but I haven't done anything myself around that and we haven't done anything as a university around that either. I don't think this is new, but when you are faced with a potential skills shortage, what you should be doing is looking at a whole range of different strategies, one of which is building the pipeline from the bottom. Not just going out at an international level and saying, "we will just get them from somewhere". It needs to be a range of different strategies and building that pipeline’ (University). 
Rothwell (2010) highlights the importance of identifying, nurturing and promoting talent from within and having established pipelines of talent coming through, to ensure an organisation meets its strategic objectives. Succession planning does not appear to be a high priority for Australian universities (Larkin \& Neumann, 2012). No participant universities in this study reported having established pipelines of potential leaders. This is because universities want to appoint the best academics and researchers, and, in the view of many participants, this means an international appointment. This is mainly because universities want to elevate their research standing. These findings are consistent with the view of Scott, Coates and Anderson, (2008), who suggest that Australian universities are doing little to address pending recruitment challenges, and that they do not have structured succession strategies in place.

Succession planning has obvious benefits, such as not having to compete either locally or globally for talent. Other benefits are reducing costs (not requiring executive search to attract talent) and being able to retain university knowledge, loyalty and established cultures (Larkin \& Neumann, 2012; McMurray et al., 2012).

Possible reasons for the neglect of succession planning at Australian universites include a tendency to appoint senior leaders on relatively short-term contracts with diminished focus on long-term strategic initiatives, such as workforce planning. Further it appears that humanresource departments are stretched to their financial and staffing capacity and may not have suitable personnel to implement succession planning across the university.

\section{Increasing use of Executive Search Firms}

As a result of growing competition, an aging academic workforce, the declining attractiveness of academia and lack of succession planning there is a increasing need to use executive search firms to attract quality senior academic leaders.

Executive search, sometimes called 'head-hunting,' is the process by which an organisation pays a recruitment agency to assist with the recruitment process (Compton, Morrissey, \& Nankervis, 2009; Nankervis, Compton, Baird, \& Coffeey, 2011; Stone, 2011; Tienari, Meriläinen, Holgersson, \& Bendle, 2013).

Historically, university human resource departments would manage the recruitment and selection of senior academic leaders. This research reveals that there has been a shift to contracting executive search firms to source quality academic leaders. This is consistent with research into executive search in other sectors, as the labour market tightens there is a tendency to use executive search for senior appointments (Fernández-Mateo \& Fernández, 2016; McGraw, 2011; Shulman \& Chiang, 2007; Tienari et al., 2013).

Executive search does not come cheap. Stone (2011) reports that typically the cost of executive search in Australia is between 25-40 per cent of the total remuneration (first year), which is paid in three instalments; the fee is paid whether a candidate is hired or not, and expenses are billed separately. In the UK, the executive search fee is usually equivalent to one-third of the first year's salary. Normally 50 per cent is paid up front and the other 50 per cent is paid once the appointment is made (Faulconbridge, Beaverstock, Hall, \& Hewitson, 2009).

This study revealed a lack of traction through university advertising when recruiting senior academic leaders and, therefore, a perceived need to use executive search firms. A recurring theme throughout the interviews was that only around 10 per cent of candidates come through advertising. 
One executive search director stated:

'After having been a human resource director for a long time, when I first started to get into the search arena I got a shock. I got a shock because job ads were simply not effective. Whereas, in the time I had been HR Director, you usually got a pretty decent field, and you know, but not always, you just readvertised. So I saw the lack of interest and the lack of response to ads, I realised that something fundamental had shifted' (Executive Search).

When responding to research question 2 (p. 3), the majority of participants in this study identified that their University uses executive search firms to recruit their senior academic leaders (Table 2).

\begin{tabular}{|c|l|}
\hline \multicolumn{2}{|c|}{ Use of Executive Search } \\
\hline Case Study & \multicolumn{1}{c|}{ Comment } \\
\hline One & Every senior appointment is outsourced to executive search \\
\hline Two & $\begin{array}{l}\text { Mostly executive search depending on how difficult they feel it would be } \\
\text { to source a suitable pool of candidates }\end{array}$ \\
\hline Three & Always use an executive serch firm \\
\hline Four & $\begin{array}{l}\text { VC or DVC would make the decision whether to use executive search } \\
\text { firms. In most cases executive search is used }\end{array}$ \\
\hline Five & $\begin{array}{l}\text { Executive search is used for all senior appointments, this is a directive from } \\
\text { the VC }\end{array}$ \\
\hline Six & Never use executive search \\
\hline Seven & Executive search is used in nearly every instance \\
\hline Eight & Executive search used in most cases depending on the budget \\
\hline Nine & Always use executive search firms \\
\hline Ten & Internal expression of interest; if not success, then executive search used. \\
\hline
\end{tabular}

\section{Table 2. $\quad$ Use of Executive Search Firms by Universities}

It was also clear from the interviews that whilst universities were aware that they attracted very few quality candidates through advertising, they knew that the advertisements also served to show transparency in the recruitment process and provided brand awareness.

Several participants also stated that one of the reasons it is hard to attract quality candidates through advertising is that people are too busy to respond to ads. They mean to, but do not get around to it:

'One of things that has shifted is that people are so busy, unless they have actively said, 'it's time for me to move', they just don't bother. Even though they look at a job and might say it's all right but I'm just too busy and can't fit it in. But when they get the phone call to say "Have you thought about this?" that's the little bit of motivation that gets them moving' (Executive Search).

As a result of a diminishing pool of academic talent, executive search firms are being used to tap into what is called 'passive talent', candidates who are not really looking for work or seeking to change employers. There is a perception by universities and executive search that passive talent results in a better quality candidate. 
The executive search firm aims to convince individuals to go to another organisation with gentle persuasion, often around the benefits of the move, such as career progression and increased remuneration. Fernandez-Mateo and Fernandez (2016) report that executive search firms draw up a list of potential candidates for a particular role and the prospect may not know they are on the list.

Participants stated that the main reason universities use executive search is that they do not believe they have the capacity themselves to source a wide range of high-quality candidates, particularly if they are aiming to attract international candidates. This finding is consistent with what has been reported in the literature (Holm, 2012; Meriläinen, Tienari, \& Valtonen, 2013; Tienari et al., 2013). Another reason is that recruitment is time-consuming, and universities may not have the human resource management capacity to manage the process. Moreover, executive search consultants have extensive knowledge of the sector and a deep understanding of recruitment practices; therefore, their expertise and insight can facilitate the sourcing of high-quality candidates.

'There are less and less people, we are all chasing the one pool, all the universities. At these senior-level appointments there are no new people around. That is why we changed the way we are recruiting, going with search firms to the passive people' (University).

Executive search firms have extensive local and international databases at their disposal and research teams (some larger than others) to source passive talent. These teams trawl through university websites, on-line portals such as LinkedIn and Facebook, and access conference attendee lists to find passive talent. General feedback from the executive search firms is that around ninety per cent of candidates come from headhunting and 10 per cent from ads.

One executive search participant stated:

'Our main avenue to putting together a successful list of candidates is frankly 'blue sky' research that is often a lot of desktop research. One of the beauties of working in higher education is that everybody has a profile and often a $C V$ online. If we want to know who John Smith is at XXX University, at a minimum we would get a one-page summary that says John Smith does this, this is his research area, and here are his contact details. You often don't get that in industry' (Executive Search).

It became obvious throughout the interviews that executive search participants had a very sound understanding and knowledge of the higher education sector. Because they are in discussions with, and liaising with, senior academic leaders across a range of universities, they are familiar with what is happening, not only from a government and policy point of view, but also with regard to the intricacies of university operations.

Whilst the cost of executive search is high, universities believe the investment is worth it as it is crucial for them to make successful appointments. They understand the ramifications of a poor senior academic appointment, which not only can affect staff morale, it can also damage the university's reputation.

Though executive search may appear relatively straightforward and inconsequential, it can have broader implications for both the organisation and the workforce. Faulconbridge et al. 
(2009) report that the executive search firms presents a list of candidates to an employer, and that this places the firm in a position of power to control the elite labour market. For example, the initial screening of candidates for a university senior leadership position is conducted by the executive search firm, who may screen out candidates the university might have shortlisted.

Qualitative research conducted by Hamori (2010) examined the way in which executive search firms shape career moves and structure labour markets. Her findings are consistent with that of Faulconbridge et al. (2009), and Cappelli and Hamori (2013), stating that executive search firms structure the labour market by choosing 'talent' from only high-quality organisations that have good reputations, and often from a defined pool of well-performing organisations. In university terms this may equate to selecting candidates from universities that perform well in ranking tables and have external accreditation, such as that of the Association to Advance Collegiate Schools of Business (AACSB), Engineers Australia, the NSW Nursing Board or the Australian Health Practitioner Regulation Agency (AHPRA).

By encouraging the movement of individuals, many of whom are not actively looking for a new employer, executive search firms 'simultaneously demolish and create career boundaries' (Hamori, 2010 p.56). In other words, whilst they are finding quality potential candidates for one university, they may be poaching them from another, and in the process, generating new job opportunities for their own business.

Based on the brief provided by the university, executive search firms are selecting candidates to put forward for senior academic leadership positions demonstrating a growing influence over who will lead our universities of the future. While executive search firms are interested in making a successful appointment, their business model differs from that of universities, as it is a model based on a making a profit. This research highlights opportunities for further research investigating the following questions:

- what are the implications of this shift in power towards executive search firms engaged in university recruitment and selection?

- should Universities recruit staff who have executive search experience so the executive search process can be managed from within the university?

- do Human Resource Directors need special skills/understandings in managing search firms?

- what strategies and development programs can universities implement to develop senior staff leadership capabilities?.

\section{CONCLUSION}

This research identified key factors impacting the recruitment and selection of senior academic leaders in Australian universities including growing competition for staff and students from within Australia and overseas, an aging academic workforce, the declining attractiveness of academia as a profession and a lack of succession planning. This combination of factors has made it increasingly difficult for universities to attract quality senior academic leaders. Traditional methods of recruitment, such as advertising a position, are no longer effective, therefore, universities have turned to executive search firms to help them recruit senior staff. By this process universities divest themselves of funds and influence over selection of candidates for leadership positions. It is expensive to use executive search firms and also implies that universities are handing over some of the control and power to executive search firms that may skew the type of candidates being presented to universities as part of the recruitment process. Ideally, universities would be better served by recruiting their own staff, 
perhaps from their large pools of sessional academic staff, however this would need comprehensive workforce planning that includes succession planning, professional development and mentoring to build their workforce from within. To facilitate this universities would need to invest in staff who specialise in recruitment and selection along with workforce planning and implementation. While advocating recruitment from within, the authors of this paper recognise that it is important to also bring in staff from outside the university with new ideas and ways of doing things. As competition for staff and students increases and as the baby boomers exit the workforce it is going to becoming increasingly difficult for universities to recruit quality senior academic leaders. The universities that make a serious investment and commitment to workforce planning by building future talent from within will not only retain university knowledge, loyalty and established culture but foster a true commitment from current staff and be seen as an employer of choice from those outside the university. 


\section{References}

Angen, M. (2000). Pearls, Pith, and Provocation: Evaluating Interpretive Inquiry: Reviewing the Validity Debate and Opening the Dialogue. Qualitative Health Research, Vol 10(No 3), pp. 378-395.

Archer, W. (2005). Mission Critical? Modernising Human Resource Management in Higher Education Higher Education Policy Institute. Retrieved from http://www.hepi.ac.uk/466-1170/Mission-Critical-Modernising-Human-ResourceManagement-in-Higher-Education.html

Australian Government. (2015a). Future Directions for Streamlined Visa Processing Retrieved from https://www.border.gov.au/ReportsandPublications/Documents/reviews-andinquiries/future-directions.pdf

Australian Government. (2016b). National Innovation and Science Agenda. Retrieved from Retrieved from http://www.arc.gov.au/news-media/news/national-innovation-andscience-agenda

Australian Government. (2016c). Risk Assessment Framework Version 2.1. Retrieved from http://www.teqsa.gov.au/regulatory-approach/risk-assessment-framework

Australian Government. (2017). Selected Higher Education Statistics - 2017 Staff Data. Retrieved from https://www.education.gov.au/selected-higher-education-statistics2017-staff-data

Australian Government. (2017d). Higher Education Standards Framework 2015. Retrieved from https://www.teqsa.gov.au/higher-education-standards-framework-2015

Bexley, E., Arkoudis, S., \& James, R. (2012). The motivations, values and future plans of Australian Academics Higher Education, 65(3).

Bradley, D., Noonan, P., Nugent, H., \& Scales, B. (2008). Review of Australian Higher Education Retrieved from http://www.deewr.gov.au/highereducation/review/pages/reviewofaustralianhigheredu cationreport.aspx

Brown, W., \& Moshavi, D. (2002). Herding academic cats. Journal of Leadership Studies(Winter), 79.

Cappelli, P., \& Hamori, M. (2013). Understanding Executive Job Search Organization Science. Retrieved from https://pubsonline.informs.org/doi/abs/10.1287/orsc.2013.0871

Coates, H., Dobson, I., Edwards, D., Friedman, T., Goedegebuure, L., \& Meek, L. (2009). Research Briefing, Changing Academic Profession (October ). Retrieved from http://research.acer.edu.au/higher_education/11/

Coates, H., \& Goedegebuure, L. (2012). Recasting the Academic Workforce: Why the Attractiveness of the Academic Profession Needs to Be Increased and Eight Possible Strategies for How to Go about This from an Australian Perspective. Higher Education: The International Journal of Higher Education and Educational Planning, 64(6), 875889.

Coates, H., Goedegebuure, L., Van Der Lee, J., \& Meek, L. (2008). The Australian Academic Profession: a first overview, 179-202. Retrieved from https://minervaaccess.unimelb.edu.au/handle/11343/28915

Compton, R., Morrissey, W., \& Nankervis, A. (2009). Effective Recruitment and Selection Practices (5th ed.). Sydney: CCH Australia Ltd.

Cox, K. (2010). The backyard and beyond. Big picture recruitment. Retrieved 29/01/2014 http://w3.unisa.edu.au/news/opinion/2010/May_7.asp

Creagh, S. (2011). Review of International Student Visa Rules. The Conversation, (20/10/11). Retrieved from http://theconversation.edu.au/universities-welcome-knight-review-ofinternational-student-visa-rules-3504 
Deloittes Access Economics. (2015). Growth and Opportuntiy in Australian International Education A report prepared for Austrade, (December). Retrieved from https://www.austrade.gov.au/Australian/Education/Services/australian-internationaleducation-2025/growth-and-opportunity

Department of Education and Training. (2011). Fact Sheet: Demand Driven Funding for Undergraduate Student Places(23/08/2012). Retrieved from https://www.education.gov.au/report-review-demand-driven-funding-system

Department of Immigration and Citizenship. (2012). Implementation of the Government Response to the Knight Review of the Student Visa Program. Retrieved from http://www.immi.gov.au/students/knight/

Ernst \& Young. (2012). University of the future Retrieved from https://www.ey.com/au/en/newsroom/news-releases/australian-universities-on-thecusp-of-profound-change---ernst-and-young-report

Ernst \& Young. (2018). Can the universities of today lead learning tomorrow. Retrieved from https://www.ey.com/au/en/industries/government---public-sector/ey-university-of-thefuture-2030

Faulconbridge, R., Beaverstock, J., Hall, S., \& Hewitson, A. (2009). The 'war of talent': The gatekeeper role of executive search firms. Geoforum, 40, 800-808.

Fernández-Mateo, I., \& Fernández, R. (2016). Bending the Pipeline? Executive Search and Gender Inequality in Hiring Top Management Jobs Management Science, 62(12), 3636-3655.

Fullan, M., \& Scott, G. (2009). Turnaround Leadership for Higher Education. San Francisco Jossey Bass Wiley.

Group of Eight. (2012). Policy Note: University Admissions Retrieved from http://www.go8.edu.au/_documents/go8-policyanalysis/2012/go8policynote3_universityadmissions.pdf

Group of Eight. (2014). Future Demand for Higher Education in Australia. Retrieved from https://go8.edu.au/publication/future-demand-higher-education-australia

Hamori, M. (2010). Who Gets Headhunted--and Who Gets Ahead? The Impact of Search Firms on Executive Careers. Academy of Management Perspectives, 24(4), 46-59. doi:10.5465/amp.2010.55206384

Harman, G. (2003). Academic Leaders or Corporate Managers: Deans and Heads in Australian Higher Education, 1977 to 1997. Higher Education Management and Policy, Vol 1. Retrieved from https://doi.org/10.1787/hemp-v14-art13-en

Holm, A. B. (2012). E-recruitment: Towards an Ubiquitous Recruitment Process and Candidate Relationship Management. German Journal of Research in Human Resource Management, 26(3), 241-259. Retrieved from http://journals.sagepub.com/doi/abs/10.1177/239700221202600303

Hugo, G. (2005). Demographic Trends in Australia's Academic Workforce. Journal of Higher Education Policy and Management, 27(3), 327-343.

Hugo, G., \& Morriss, A. (2010). Investigating The Aging Academic Workforce: Stocktake24/05/11, 1-98. Retrieved from Universities Australia website: http://www.hru.uts.edu.au/docs/forum/hugo_morriss.pdf

Kent, M. (2006). Not Dead, but may be extinct: The University in Australia. Australian Quarterly 78(6), 4-8.

Knott, M. (2017). No need for a 'dramatic overhaul': Universities Australia warns against radical reform. Sydney Morning Herald (January ). Retrieved from https://www.smh.com.au/politics/federal/no-need-for-a-dramatic-overhauluniversities-australia-warns-against-radical-reform-20170123-gtx06o.html 
Larkin, J., \& Neumann, R. (2012). Ageing Academics: Workfore Priorities for Universities International Journal of Employment Studies, 20(1), 3-24.

Marginson, S., \& Considine, M. (2000). The Enterprise University: Power, Governance and Reinvention in Australia. United Kingdom Cambridge University Press.

Mazzolini, M. (2012, 10/10/2012). Shaping up to jump TEQSA's bar. Campus Review, 22, 7.

McCarthy, G., \& Loomes, S. (2011). The Aging Workforce: How Can Australian Universities Address Future Workforce Challenges? Paper presented at the ANZAM Conference, Wellington.

McGraw, P. (2011). Recruitment and Selection Australian Master Human Resource Guide (9th ed.). Sydney CCH Australia Limited

McMurray, A., Henly, D., Chaboyer, W., Clapton, J., Lizzio, A., \& Teml, M. (2012). Leadership succession management in a university health faculty Journal of Higher Education Policy \& Management, 34(4), 365-376.

Meriläinen, S., Tienari, J., \& Valtonen, A. (2013). Headhunters and the 'ideal' executive body. Organization, 22(1), 3-22. doi:10.1177/1350508413496578

Middlehurst, R., Goreman, H., \& Woodfield, S. (2009). Why Research Leadership in Higher Education? Exploring Contributions from the UK's Leadership Foundation for Higher Education. 5(3), 311-329.

Nankervis, A., Compton, R., Baird, M., \& Coffeey, J. (2011). Human resource management : strategy and practice (7th ed.). South Melbourne Victoria Cengage Learning Australia.

Ng, P. (2013). The global war for talent: responses and challenges in the Singapore higher education system. Journal of Higher Education Policy and Management, 35(3), 280292.

Noonan, P., \& Pilcher, S. (2018). Participation in tertiary education in Australia, Modelling and scenario analysis(April ). Retrieved from http://www.mitchellinstitute.org.au/wpcontent/uploads/2018/04/Participation-in-tertiary-education-in-Australia.pdf

Norton, A. (2013). Taking University Teaching Seriously Retrieved from https://grattan.edu.au/report/taking-university-teaching-seriously/

Norton, A. (2017). Demand for cuts deals death blow to Australia's demand-driven system. Retrieved from https://grattan.edu.au/news/demand-for-cuts-deals-death-blow-toaustralias-demand-driven-system/

Rothwell, W. (2010). Effective Succession Planning: Ensuring Leadership Continuity and Building Talent from Within (Fourth ed.). New York American Management Association

Scott, G., Coates, H., \& Anderson, M. (2008). Learning Leaders in Times of Change Academic Leadership Capabilities for Australian Higher Education. Retrieved from https://research.acer.edu.au/higher_education/3

Shulman, B., \& Chiang, G. (2007). When to use an executive search firm and how to get the most out of the relationship. Employment Relations Today (Wiley), 34(1), 13-19.

Stone, R. (2011). Human Resource Management (7th Edition ed.). Milton: John Wiley \& Sons Australia Ltd

Tienari, J., Meriläinen, S., Holgersson, C., \& Bendle, R. (2013). And then there are none: on the exclusion of women in processes of executive searach Gender in Management: An International Journal, 28(1), 43-62.

Universities Australia. (2012). Universities Australia Submission to the Development of an International Education Strategy for Australia. Retrieved from https://aei.gov.au/IEAC2/Submissions(IEAC)/Documents/20.\%20Universities\%20Au stralia.pdf 
Universities Australia. (2016). Keep it Clever: Policy Statement 2016. Retrieved from https://www.universitiesaustralia.edu.au/news/policy-papers/Keep-it-Clever--PolicyStatement-2016\#.WinZKbpuKhc

Universities UK. (2007). Policy Briefing; Talent Wars. Retrieved from http://www.universitiesuk.ac.uk/Publications/Documents/Policy\%20Brief\%20Talent \%20Wars.pdf

West, R. (1998). Learning for Life: Final Report - Review of Higher Education Financing and Policy Retrieved from http://www.voced.edu.au/content/ngv\%3A30787

Wolverton, M., \& Poch, S. (2000). The Nexus Between Academic Deans and Corpoprate CEO's: An Opportunity in the Making. Journal of Leadership Studies, 7(3), 122-132.

Yielder, J., \& Codling, A. (2004). Management and Leadership in Contemporary Universities. Journal of Higher Education Policy and Management, 26(3), 315-328. 